\title{
The Effect of Interleukin-17 on Hematopoietic Cells and Cytokine Release in Mouse Spleen
}

\author{
G. JOVČIĆ, D. BUGARSKI, A. KRSTIĆ, M. VLAŠKI, M. PETAKOV, \\ S. MOJSILOVIĆ, N. STOJANOVIĆ, P. MILENKOVIĆ
}

Institute for Medical Research, Beograd, Serbia

Received January 13, 2006

Accepted April 6, 2006

On-line available June 22, 2006

\begin{abstract}
Summary
To evaluate whether the response of hematopoietic cells to interleukin-17 (IL-17) depends on the tissue microenvironment in which hematopoiesis occurs, the influence of recombinant mouse IL-17 on spleen hematopoietic cells and cytokine release was assessed in normal mice in vitro and in vivo. In vitro, IL-17 did not significantly affect the growth of granulocyte-macrophage (CFU-GM) and erythroid (BFU-E and CFU-E) derived colonies. A single injection of IL-17 in vivo exhibited stimulatory effects on hematopoietic cells from both granulocytic and erythroid lineages. The increased number of metamyelocytes $48 \mathrm{~h}$ after treatment imply to the IL-17-induced stimulation of granulopoiesis. The number of BFU-E was increased at $24 \mathrm{~h}$, while the number of CFU-E increased $6 \mathrm{~h}$ and $24 \mathrm{~h}$ after treatment. Since the same treatment in the bone marrow decreased the number of CFU-E, it may be concluded that the local microenvironment plays an important role in IL-17-mediated effects on CFU-E. IL-17 increased the release of IL6 both in vitro and in vivo, but showed tendency to suppress the constitutive secretion of IL-10 by spleen cells. Our results suggest the complexity of target cell response and interplay of secondary induced cytokines by IL-17 in different hematopoietic organs.
\end{abstract}

\section{Key words}

Interleukin-17 • Mouse spleen $\bullet$ Hematopoietic cells $\bullet$ Cytokine release

\section{Introduction}

Interleukin-17 (IL-17), also referred to as IL$17 \mathrm{~A}$, is a prototype member of a new cytokine family recently identified as a distinct ligand-receptor system. IL-17 is produced mainly by activated $\mathrm{CD} 4^{+}$and $\mathrm{CD} 8^{+}$ memory $\mathrm{T}$ lymphocytes. In contrast to the restricted expression of IL-17, its receptor is ubiquitous in most tissues (Mosely et al. 2003, Witowski et al. 2004). Due to the ability of IL-17 to induce the release of many mediators of inflammation it has been characterized as proinflammatory cytokine. Accumulating evidence has pointed to the important role of IL-17 in the T-cellmediated inflammatory response. In addition, it was suggested that IL-17 within a complex network of interactive cytokines contributes to the maintenance of homeostasis and the pathogenesis of many diseases (Gaffen 2004).

Acting on a wide range of stromal cells, IL-17 stimulates the production of numerous proinflammatory 
mediators, hematopoietic cytokines and chemokines, particularly those that are involved in the proliferation, maturation and chemotaxis of neutrophils (Fossiez et al. 1998, Schwarzenberger and Kolls 2002, Witowski et al. 2004). It was suggested that IL-17 provides an important link between the immune system and hematopoiesis, mostly exhibiting the effects on hematopoiesis via the induction of secretion of secondary cytokines. However, the involvement of IL-17 in the regulation of hematopoiesis is not completely known. It was demonstrated that IL-17 stimulates granulopoiesis by expanding myeloid progenitors and increasing of mature neutrophils in peripheral blood (Schwarzenberger et al 1998, 2000). On the other hand, our previous data, both in vitro and in vivo, have shown that IL-17 besides the influences on granulocytic cells affects erythroid progenitor cell compartments in the bone marrow of normal mice (Jovčić et al. 2001, 2004).

In order to accumulate more data concerning the hematopoietic effects of IL-17 the aim of the present study was to evaluate the influence of IL-17 on mouse spleen hematopoetic cells and cytokine release in vitro, as well as in vivo, in normal mice. Namely, the spleen is also an active hematopoietic organ in rodents and the hematopoietic microenvironment of mouse spleen in vivo predominantly supports the differentiation of hematopoietic progenitors into erythroid lineage. Therefore, our approach was to assess whether the response of hematopoietic cells to IL-17 action depends on the tissue microenvironment in which hematopoiesis occurs. To investigate in vitro effects of IL-17 on hematopoietic progenitor cells, the influence of increasing concentrations of recombinant mouse IL-17 (rmIL-17) on the growth of granulocyte-macrophage (CFU-GM) and erythroid (BFU-E and CFU-E) derived colonies was determined. Since stromal cells play a crucial role in the regulation of hematopoiesis, and the cytokine profile induced by IL-17 depends on the cell type that is exposed to IL-17 (Jovanović et al. 1998, Fossiez et al. 1998), the in vitro effects of increasing concentrations of IL-17 on the secretion of cytokines such as IL-6, IL-10, IGF-I and IFN- $\gamma$ by spleen cells were also determined. To elucidate the in vivo biological activity of IL-17, the effects of single intravenous administration of rmIL-17 on spleen CFU-GM, BFU-E and CFU-E progenitor cell compartments and morphologically recognizable cells were analyzed at different time intervals after the treatment. At the same time points, the influence of IL-17 on the release of secondary cytokines by spleen cells was determined. In addition, the effect of IL-17 administration on metabolic activity/viability of spleen cells was examined.

\section{Methods}

Mice

Normal adult inbred male CBA mice, 6 to 8 weeks old, weighing 20-22 g, (Breeding Facilities of the Institute for Medical Research, Military Medical Academy, Belgrade) were used for the experiments. The animals were housed under conventional conditions, with food and water provided ad libitum.

\section{In vitro experiments}

Spleens harvested under sterile conditions were gently passed through a wire mash and monodispersed in medium by passing the cell suspension several times through a 20-gauge needle. The spleen cell suspensions were prepared in Dulbecco's modified Eagle's medium (DMEM, Sigma, St. Louis, MO, USA) supplemented with $5 \%$ fetal calf serum (FCS, Sigma, St. Louis, MO, USA) and the cells were counted using a hemocytometer. To evaluate the influence of recombinant mouse IL-17 (R\&D Systems, Minneapolis, MN, USA) on the growth of hematopoietic progenitor cells derived colonies, CFUGM, BFU-E and CFU-E, spleen cells were cultured in the presence of increasing concentrations $(0,50,100$, $500 \mathrm{ng} / \mathrm{ml}$ ) of IL-17 using a methylcellulose culture system. The experiments were replicated at least three times. For the determination of IL-17 effects on cytokine release (IL-6, IL-10, IGF-I and IFN- $\gamma$ ), spleen cell suspensions $\left(5 \times 10^{6} / \mathrm{ml}\right)$ were incubated with the same increasing concentrations of IL-17, or with medium as control, for $48 \mathrm{~h}$ at $37{ }^{\circ} \mathrm{C}$ in humidified atmosphere with $5 \% \mathrm{CO}_{2}$ in air. Cell-derived conditioned media were harvested and stored at $-20{ }^{\circ} \mathrm{C}$ until cytokine assays. These experiments were performed at least twice.

\section{In vivo experiments}

The animals received $1 \mu \mathrm{g}$ of IL-17 dissolved in saline and injected i.v. in a volume of $0.2 \mathrm{ml}$. To distinguish IL-17-mediated effects from the effects induced by injection procedure itself, besides untreated mice, saline-treated mice were also used as controls. Mice were sacrificed at 6, 12, 24, 48 and $72 \mathrm{~h}$ after treatment. In the spleen of each animal the following hematological parameters were estimated: the number of CFU-GM, BFU-E and CFU-E derived colonies, the total 
number of nucleated cells and differential count of morphologically recognizable cells. To estimate the effects of IL-17 administration on the release of IL-6, IL-10, IGF-I and IFN- $\gamma$ by spleen cells, at the same time points after treatment, spleen cell suspensions $\left(5 \times 10^{6} / \mathrm{ml}\right)$ were prepared from each animal in DMEM supplemented with $5 \%$ FCS and incubated for $48 \mathrm{~h}$ at $37{ }^{\circ} \mathrm{C}$ in humidified atmosphere with $5 \% \mathrm{CO}_{2}$ in air. Cell-derived conditioned media were collected and stored at $-20{ }^{\circ} \mathrm{C}$ until cytokine assays. The experiments were performed on 4 to 6 animals per group for each time point and were repeated at least three times.

\section{Colony forming assays}

The number of hematopoietic progenitor cells was determined using a methylcellulose culture system. For CFU-GM and BFU-E determination MethoCult GF M3434 methylcellulose medium with recombinant cytokines $(50 \mathrm{ng} / \mathrm{ml} \mathrm{rmSCF}, 10 \mathrm{ng} / \mathrm{ml} \mathrm{rmIL-3,} 10 \mathrm{ng} / \mathrm{ml}$ rhIL-6 and 3 units $/ \mathrm{ml}$ rhEpo, Stem Cell Technologies, Vancouver, BC, Canada) was used, following the instructions of the manufacturer. For CFU-E estimation MethoCult M 3334 with recombinant erythropoietin ( 3 units $/ \mathrm{ml}$ ) were only used. Briefly, $4 \times 10^{5}$ nucleated spleen cells were suspended in $1 \mathrm{ml}$ of methylcellulose medium, plated in duplicate in $35-\mathrm{mm}$ tissue culture dishes and incubated at $37^{\circ} \mathrm{C}$ in a humidified atmosphere with $5 \% \mathrm{CO}_{2}$ in air. The number of colonies was counted on day 2 for CFU-E and day 7 for CFU-GM and BFU-E using an inverted microscope.

\section{Estimation of morphologically recognizable spleen cells}

The smears of spleen cells were stained by the May-Grunwald-Giemsa procedure and 1000 nucleated cells on each smear were differentiated morphologically and divided into following compartments: metamyelocytes, mature granulocytes, monocytes, lymphocytes, erythroblasts and orthochromatic blasts.

\section{Cytokine determination}

Measurement of IL-6, IL-10 and IFN- $\gamma$ levels in spleen cell-derived conditioned media was performed using ELISA kits following instructions provided by R\&D Systems (Minneapolis, MN, USA). The IGF-I concentrations were determined using radioimmunoassay kit (INEP, Zemun, Serbia). The sensitivity of these assays enables detection of cytokine concentrations as low as 1.6 $\mathrm{pg} / \mathrm{ml}$ for IL-6, $4 \mathrm{pg} / \mathrm{ml}$ for IL-10, $2 \mathrm{pg} / \mathrm{ml}$ for IFN- $\gamma$ and $2 \mathrm{pg} / \mathrm{ml}$ for IGF-I.

\section{MTT assay}

To assess the effect of IL-17 administration on metabolic activity/viability of spleen cells a quantitative colorimetric MTT assay was employed. MTT is a yellowcolored tetrazolium salt, 3-(4,5-dimethyl-thiazol-2yl)-2,5 diphenyl-tetrazolium bromide, that is taken up and cleared only by metabolically active cell, reducing it to colored end product, formazan (Mosmann 1983). Spleen cell suspensions made of spleens obtained from normal, non-treated mice and animals treated with IL-17 or saline after $6,12,24,48$ and $72 \mathrm{~h}$ of treatment were plated into a 96 -well culture plates at $5 \times 10^{5}$ cells/well in a $100 \mu \mathrm{l}$ volume in triplicates. Immediately or following $24 \mathrm{~h}$, MTT solution $(5 \mathrm{mg} / \mathrm{ml}, 10 \mu \mathrm{l} /$ well $)$ was added and the cultures were incubated for the additional $3 \mathrm{~h}$ at $37^{\circ} \mathrm{C}$ in a humidified atmosphere. Formazan produced by the cells was dissolved during overnight incubation in SDS-HCl $(10 \% \mathrm{SDS}, 0.1 \mathrm{~N} \mathrm{HCl})$ and subsequently its absorbance was measured at $540 \mathrm{~nm}$ in an ELISA 96-well plate reader (Labsystem Multiskan PLUS, Finland).

\section{Statistical analysis}

Statistical analysis was performed by Student's t-test, using the Origin PC Program with the actual numbers of each investigated parameter. Data are expressed as means \pm S.E.M., and $p<0.05$ value was considered to be statistically significant.

\section{Results}

In vitro effects of IL-17 on spleen cells of normal mice Influence of IL-17 on progenitor cells

To evaluate the hematopoietic effects of IL-17 on spleen cells in vitro, the influence of increasing concentrations of IL-17 on the growth of granulocytemacrophage and both the immature and mature erythroid progenitor cells was determined. The results obtained did not reveal significant changes in the number of hematopoietic progenitor cells derived colonies. In fact, under the influence of IL-17 the number of CFU-GM showed the tendency to increase, while the number of BFU-E and CFU-E tended to decrease (data not shown).

\section{Influence of IL-17 on cytokine release by spleen cells}

Measurement of IL-17-mediated release of IL-6, IL-10, IGF-I and IFN- $\gamma$ by spleen cells demonstrated that IL-17 affects the constitutive secretion of IL-6 and IL-10, while the secretion of IGF-I and IFN- $\gamma$ was below detectable levels. Significant $(p<0.05)$ stimulation of IL- 6 
a)

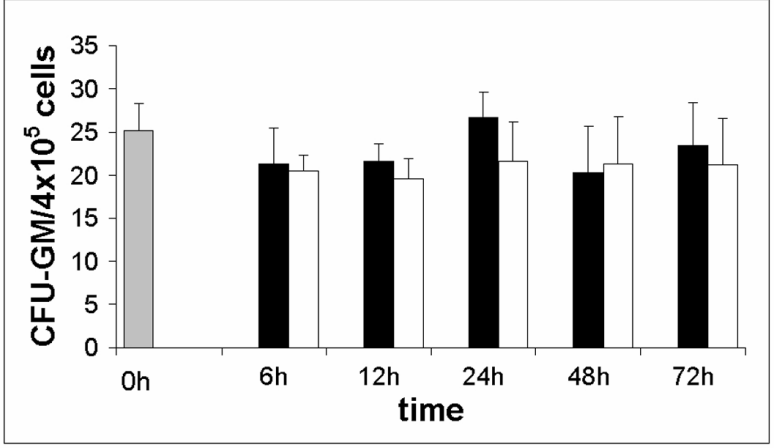

b)

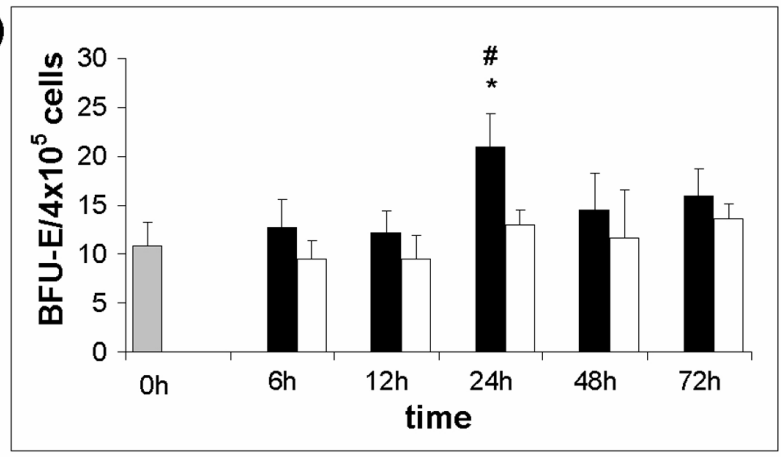

c)

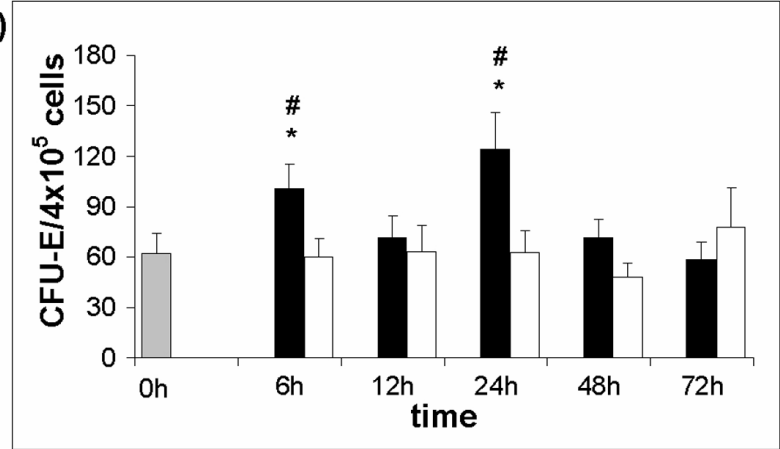

Fig. 1. The influence of a single dose of rmIL-17 on spleen (a) CFU-GM, (b) BFU-E and (c) CFU-E-derived colonies growth in normal mice at different time points after administration. The data points represent means \pm S.E.M. of three to six experiments each performed in duplicate. (ロ) IL-17-treated mice; ( $\square$ ) salinetreated mice; ( $\square$ ) non-treated mice. Significance at $* p<0.05$ for IL-17-treated vs. non-treated mice; and at $\# p<0.05$ for IL-17treated vs. saline-treated mice.

release induced by IL-17 was found at IL-17 concentrations of 50 and $100 \mathrm{ng} / \mathrm{ml}$ (from $41.72 \pm 2.04 \mathrm{pg} / \mathrm{ml}$ without IL-17 to $57.52 \pm 4.33 \mathrm{pg} / \mathrm{ml}$ and $54.3 \pm 4.12 \mathrm{pg} / \mathrm{ml}$ with IL-17, respectively). On the other hand, the constitutive secretion of IL-10 at the highest concentration of IL-17 used tended to be suppressed by approximately $28 \%$ (from $39.82 \pm 2.56 \mathrm{pg} / \mathrm{ml}$ without IL-17 to $28.71 \pm 4.21 \mathrm{pg} / \mathrm{ml}$ with $500 \mathrm{ng}$ IL-17/ml).

\section{In vivo effects of IL-17 on spleen cells in normal mice}

In order to assess whether the in vivo administration of IL-17 affects murine hematopoiesis in the spleen, as well as the cytokine release and metabolic activity/viability of spleen cells, a time course study (6, $12,24,48$ and $72 \mathrm{~h}$ ) after a single $i . v$. injection of IL-17 was performed.

\section{Influence of IL-17 on progenitor cells}

The number of CFU-GM derived colonies was not changed by IL-17 treatment at all observed time points, since their numbers oscillated within the values found for the non-treated as well as saline-treated mice (Fig.1a). However, the assessment of changes within erytroid progenitor cell compartments revealed that IL-17 affects both immature and mature progenitors in spleen, exhibiting stimulatory effects (Fig.1 b, c). The number of BFU-E-derived colonies was significantly increased $24 \mathrm{~h}$ after IL-17 treatment in comparison to both control groups. On the other hand, already $6 \mathrm{~h}$ after treatment with IL-17 the number of CFU-E was significantly increased in comparison to the values obtained in salinetreated or non-treated mice. The second increase in number of CFU-E under the influence of IL-17 was observed at $24 \mathrm{~h}$ and after that time their number decreased reaching the values found in control animals. Saline treatment did not induce any significant changes in the number of investigated hematopoietic progenitor cells.

Influence of IL-17 on morphologically recognizable cells

After treatment with IL-17 no significant changes in the spleen cellularity were observed. Differential counts of morphologically recognizable spleen cells demonstrated that IL-17 affects cells of the granulocytic lineage. As shown in Figure 2, IL-17 treatment induced significant increase in the absolute number of metamyelocytes $48 \mathrm{~h}$ after administration in comparison to control groups. The analysis of changes within erytroid cell compartments revealed that IL-17 induced slight non-significant increase in the absolute number of erythroblasts $12 \mathrm{~h}$ and $24 \mathrm{~h}$ after administration (data not shown). The number of lymphocytes and monocytes was not significantly altered by the IL-17 treatment at all observed time points.

\section{Influence of IL-17 on cytokine release by spleen cells}

In parallel with the determination of cellular changes within different hematopoietic cell compartments in the spleen at the same observed time points after treatment, the influence of IL-17 on the production of IL-6, IL-10, IGF-I and IFN- $\gamma$ by spleen cells was 
estimated. The measurement of their concentrations in spleen cell-derived conditioned media demonstrated that IL-17 treatment affects constitutive secretion of IL-6 and IL-10, while the concentrations of IGF-I and IFN- $\gamma$ were below detectable levels. After IL-17 administration the increased amounts of IL- 6 persisted up to $72 \mathrm{~h}$, but statistically significant higher concentrations of IL-6 were observed at $12 \mathrm{~h}$ and $24 \mathrm{~h}$ in comparison with salinetreated mice (Fig. 3). In the interval of the first 6 h, IL-17 itself had no effect on IL-6 release since both IL-17 and saline treatment caused a significant elevation of IL-6. However, in saline-treated mice after this initial rise, the concentration of IL- 6 decreased and returned to normal levels already $12 \mathrm{~h}$ after injection. The estimation of IL-10 release by spleen cells revealed that both IL-17 and saline administration led to significant increase of its secretion, but only $6 \mathrm{~h}$ after treatment (Fig. 4). However, IL-17 induced elevation of IL-10 to a lesser extent than saline did. Thereafter the concentrations of IL-10 decreased in both experimental groups and oscillated within the values found for the basal release.

\section{Influence of IL-17 on metabolic activity/viability of spleen cells}

Using MTT assay the metabolic activity/viability of spleen cells was evaluated at the same time points after IL-17 treatment. The assay was performed with cell suspensions obtained from freshly isolated spleens or following $24 \mathrm{~h}$ incubation of spleen cell suspensions. Results obtained by both protocols demonstrated that $24 \mathrm{~h}$ after IL-17 administration in the spleen of treated mice the metabolic activity/viability of the cells was significantly increased in comparison with saline-treated as well as non-treated mice (Fig. 5 a, b).

\section{Discussion}

Our previous data demonstrated that a single injection of IL-17 induced changes in the bone marrow of normal mice within different cell compartments of granulocytic and erythroid lineages, as well as affected the constitutive cytokine secretion (Jovčić et al. 2004). In order to better characterize the hematopoietic effects of IL-17, particularly in vivo, the influence of IL-17 on mouse spleen hematopoietic cells and cytokine release was assessed in the present study. The mouse spleen is an important organ for extramedullar hematopoiesis and therefore a very useful model for assaying microenvironmentally dependent effects on hematopoiesis. The results

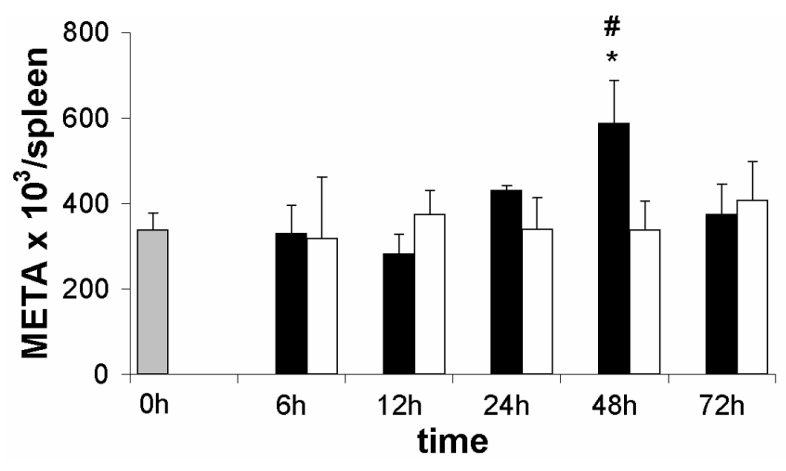

Fig. 2. The influence of a single dose of rmIL-17 on spleen metamyelocytes (META) in normal mice at different time points after administration. The data points represent means \pm SEM of three separate experiments. (ロ) IL-17-treated mice; ( $\square$ ) salinetreated mice; $(\square)$ non-treated mice. Significance at $* p<0.05$ for IL-17-treated vs. non-treated mice; and at $\# p<0.05$ for IL-17treated vs. saline-treated mice.

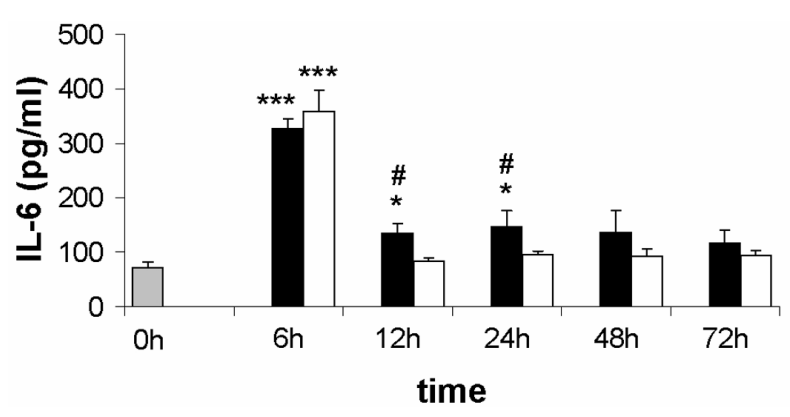

Fig. 3. In vivo effect of rmIL-17 on IL-6 release by spleen cells at different time points after administration. Values are expressed as means \pm S.E.M. ( $\square$ ) IL-17-treated mice; ( $\square$ ) saline-treated mice; ( $\square$ ) non-treated mice. Significance at $* p<0.05, * * * p<0.001$ for IL-17 and saline-treated mice vs. non-treated mice; and at $\# p<0.05$ for IL-17-treated vs. saline-treated mice.

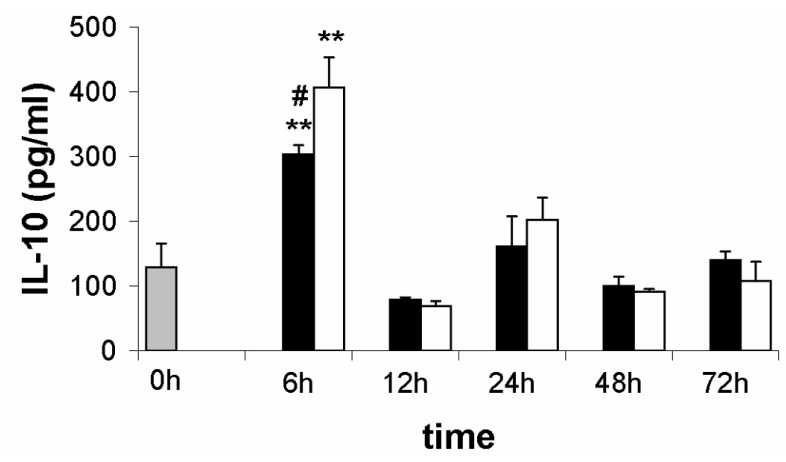

Fig. 4. In vivo effect of rmIL-17 on IL-10 release by spleen cells at different time points after administration. Values are expressed as means \pm S.E.M. ( $\square$ ) IL-17-treated mice; ( $\square$ ) saline-treated mice; $(\square)$ non-treated mice. Significance at $* * p<0.01$ for IL-17 and saline-treated mice vs. non-treated mice; and at $\# p<0.05$ for IL-17-treated vs. saline-treated mice.

obtained through combined experimental approaches in vitro and in vivo showed that IL-17 did not significantly affect the in vitro growth of granulocyte- 
a)

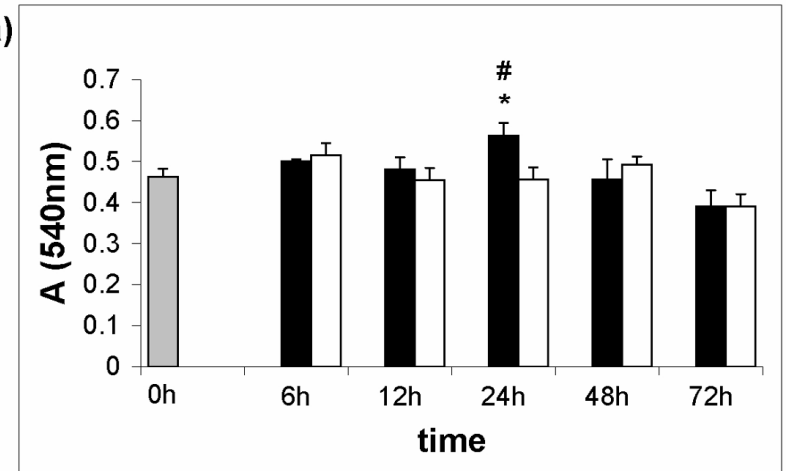

b)

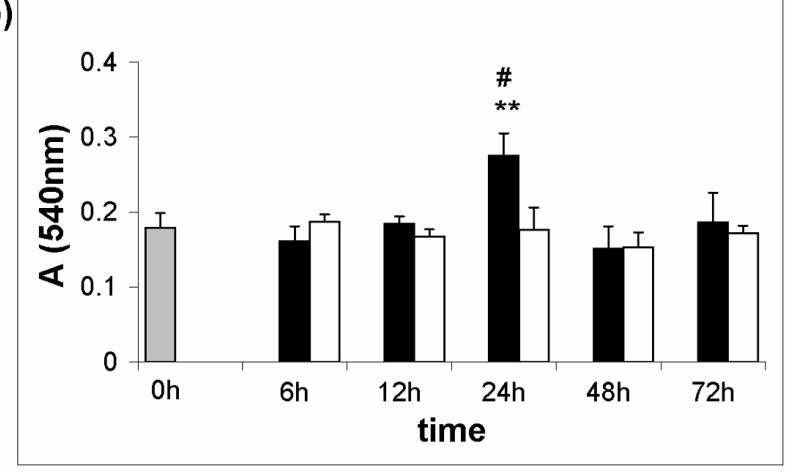

Fig. 5. In vivo effect of rmIL-17 on metabolic activity/viability of spleen cells at different time points after administration. MTT assay was performed with (a) freshly isolated spleen cells and (b) following $24 \mathrm{~h}$ incubation. MTT reduction data are expressed as absorbance at $540 \mathrm{~nm}$. Each bar represents the mean \pm S.E.M. of three separate experiments. (a) IL-17-treated mice; ( $\square$ ) saline-treated mice; $(\square)$ non-treated mice. Significance at*p $<0.05, * * p<0.01$ for IL-17-treated vs. non-treated mice; and at $\# p<0.05$ for IL-17-treated vs. saline-treated mice.

macrophage and erythroid derived colonies in spleen obtained from normal mice, while in vivo a single dose of IL-17 exhibited stimulatory effects on the hematopoietic cells from both granulocytic and erythroid lineages. This discrepancy between the in vitro and in vivo findings emphasizes that the hematopoietic effects of IL-17 in vitro may not correlate with its behavior in vivo and it confirms that in vitro data are not sufficient for accurate determination of in vivo biological function of investigated cytokine.

It is widely accepted that the regulation of constitutive hematopoiesis is mediated by locally produced growth factors and cytokines within microenvironment of hematopoietic organs. On the other hand, the effects of IL-17 on hematopoiesis are mostly attributed to the induction of secondary cytokines as for instance G-CSF, IL-6, IL-8 that can act on hematopoietic cells. The hematopoietic microenvironment of the mouse spleen contains various types of stromal cells, and all of them might be potential targets for IL-17 to induce the release of secondary cytokines. From the results presented here it is obvious that the constitutive secretion of IL- 6 and IL- 10 by spleen cells in vitro and in vivo was affected by IL-17, while the secretion of IGF-I and IFN- $\gamma$ was below detectable levels.

In accordance with the known ability of IL-17 to trigger the production of a variety of cytokines, including IL-6, IL-17 increased the release of IL-6 by spleen cells in vitro and in vivo. Since IL-17-mediated biological effects in vivo could interfere with the changes during an immediate stress-like response caused by the injection procedure itself and changes in blood volume, obtained results were analyzed and compared with two control groups, normal, non-treated and saline-treated mice. Thus, a rapid increase in the concentration of IL- 6 that was found at $6 \mathrm{~h}$ in both IL-17-treated and saline-treated mice indicates that host defense mechanisms known to induce elevation of proinflammatory cytokines were activated. However, the significant release of IL-6 that was observed $12 \mathrm{~h}$ and $24 \mathrm{~h}$ only after IL-17 administration suggests that these changes were a consequence of the action of IL-17 itself. As regards in vivo effect of IL-17 on the production of IL-6 in murine hematopoietic organs we previously reported that IL-17 potentiates IL-6 secretion both in vitro and in vivo by bone marrow cells from normal mice (Jovčić et al. 2001, 2004). However, the same IL-17 treatment in the bone marrow induced increased IL- 6 release only at $6 \mathrm{~h}$ after administration, while in the spleen, as presented here, the increased levels of IL- 6 persisted for prolonged time period. These time differences might be related to the different sensitivity of spleen cells to the action of IL-17.

Concerning IL-17-mediated changes of the constitutive release of IL-10, under experimental conditions used herein, IL-17 showed a tendency to suppress the secretion of IL-10 by spleen cells. This finding seems to be contradictory to previously reported IL-17 stimulated release of IL-10 by human macrophages (Jovanović et al. 1998). However, in our in vitro experiments, relatively high concentrations of IL-17 were required for the observed decrease of IL-10 secretion, thus indicating that its concentration could be an important factor in IL-17-mediated effects on the production of secondary cytokines. In vivo, both IL-17 and saline increased the production of IL-10 by spleen cells already $6 \mathrm{~h}$ after treatment, but IL-17 to a lesser extent than saline. The transient elevation of this antiinflammatory cytokine in both experimental groups suggests that the mechanisms towards restoring the 
disturbance caused by host defense reaction to the injection procedure itself were also activated. Although observed IL-17 effect on IL-10 release, in part, interfered with the reaction of organism to overcome the disturbed homeostasis, the fact that the level of IL-10 was significantly lower in IL-17-treated mice than in the controls, indicates that the observed finding could be at least partly attributed to the action of IL-17 itself. Since the same IL-17 treatment in the bone marrow of normal mice did not significantly alter IL-10 production in comparison with saline controls (Jovčić et al. 2004), one can suppose that IL-17-mediated release of IL-10 depends on the tissue microenvironment. In any case, further investigations, especially in vivo, are necessary for our understanding of the interplay of cytokines depending of their concentrations and local environmental factors.

The results of the present study revealed the heterogeneity of spleen hematopoietic cells that were affected in their response to IL-17 action in vivo. Estimation of the IL-17 influence on different compartments of granulocytic lineage showed no significant changes in the number of CFU-GM at all observed time points, but an increase in the number of metamyelocytes $48 \mathrm{~h}$ after treatment. Although the presence of the increased number of metamyelocytes implies the IL-17-induced stimulation of spleen granulopoiesis, the question of their origin should be taken in consideration as the number of CFU-GM remained unchanged and other direct evidence of the ability of IL-17 to stimulate spleen granulopoiesis, e.g. morphologically recognizable proliferative granulocytes, was not detected. Having in mind events that occur in the bone marrow and peripheral blood of normal mice after the same treatment with IL-17 (Jovčić et al. 2004) we can only speculate on their origin. Namely, since IL-17 had also no effect on CFU-GM in the bone marrow, one possible explanation could be that the dose of IL-17 applied in vivo was not sufficient to significantly affect CFU-GM. However, the rapid and persistent increase in the number of morphologically recognizable neutrophil precursors in the bone marrow suggested that target cells, which first respond to IL-17 action in vivo, are morphologically recognizable proliferative granulocytes. No significant alterations occurred in the number of CFU-GM, metamyelocytes and mature granulocytes in the bone marrow, as well as in the number of metamyelocytes and granulocytes in the peripheral blood during the whole observed period up to $72 \mathrm{~h}$. This indirectly indicates that granulocytic cells do not migrate from the bone marrow into the spleen under the experimental conditions used. In generall, our results are in agreement with the data indicating that IL-17 is involved in the regulation of granulopoiesis.

Estimation of IL-17 target cell range within the spleen erythroid lineage demonstrated that IL-17 in vivo affected both immature and mature erythroid progenitors by increasing their number. The fact that IL-17 enhanced the production of BFU-E in the spleen is consistent with our previous data showing that both in vitro and in vivo IL-17 exhibited stimulatory effects on BFU-E in the bone marrow of normal mice (Jovčić et al. 2001, 2004). In our previous report we also pointed to the importance of the presence of bone marrow accessory cells for IL-17mediated effects on BFU-E. Thus, one can suppose that the increase in the number of BFU-E observed in spleen $24 \mathrm{~h}$ after IL-17 administration was not caused by a direct effects of IL-17 on BFU-E, but probably was mediated through secondary induced cytokines. This assumption is supported by the fact that stimulated proliferation of BFU-E was accompanied by IL-17-mediated increased release of IL- 6 by spleen cells. Namely, it is well known that IL-6 has stimulatory effects on hematopoiesis, specifically erythropoiesis (Kishimoto 1989, Ulich et al. 1991).

In the response of spleen erythroid progenitor cell compartments to IL-17 action the first changes that were evident were those at the level of CFU-E, since already $6 \mathrm{~h}$ after IL-17 treatment an increase in the number of CFU-E was found. At the same time point after IL-17 treatment, a decreased number of CFU-E was determined in the bone marrow of treated mice (Jovčić et al. 2004). Due to the well known migration phenomenon, it cannot be excluded that following IL-17 application a communication between the spleen and bone marrow compartments exists, and the possibility of redistribution of CFU-E from bone marrow to spleen must be taken into consideration. However, our results indicate that changes in the number of CFU-E in the spleen are a consequence of their proliferation influenced by ambient regulators rather than the migration of CFU-E from bone marrow to the spleen. Our data obtained in vitro also demonstrated that IL-17 reduced the CFU-E-derived colony number in bone marrow cells from normal mice (Jovčić et al. 2001). Additionally, there is time difference between the bone marrow and spleen in the duration of changes at the level of CFU-E. In the spleen the second increase in the number of CFU-E was found $24 \mathrm{~h}$ after IL-17 administration, and thereafter their number decreased 
approaching normal values, while in the bone marrow the reduced number of CFU-E persisted up to $48 \mathrm{~h}$. Therefore, the opposite IL-17-mediated effects on CFU-E compartment, inhibitory in the bone marrow and stimulatory in the spleen, could be attributed to different cytokine profiles induced by IL-17 depending on the tissue microenvironment in which hematopoiesis occurs. Microenvironmentally dependent effects on murine hematopoiesis in vivo by other cytokines have also been reported. It was demonstrated that IL-1 can induce stimulation or inhibition of hematopoietic progenitor cells depending on their microenvironment (de Haan et al. 1993), and that administration of IL-12 to mice suppresses hematopoiesis in the bone marrow but enhances hematopoiesis in the spleen (Tare et al. 1995). Based on the facts presented above it might be concluded that local microenvironment plays an important role in IL-17-mediated effects on CFU-E compartment.

Additional evidence that a single dose of IL-17 induces significant biological changes in spleen is provided by the observation that the metabolic activity/viability of spleen cells, as measured by MTT assay, is increased $24 \mathrm{~h}$ after treatment in comparison with both controls. Namely, it is well known that this assay is recommended for the measurement of cellular proliferation, viability and cytotoxicity since MTT is metabolically reduced exclusively by living cells.

From the results presented here and our previous data it is obvious that a single dose of IL-17 elicits a cascade of in vivo biological changes in both hematopoietic organs, bone marrow and spleen, of normal mice. In conclusions, our results confirmed the involvement of IL-17 in the regulation of granulocytic cells production, indicating that more mature progenitors, morphologically recognizable neutrophil precursors, respond first to its action. Moreover, we demonstrated that IL-17 affects erythroid progenitor cell compartments expressing stimulatory effects on BFU-E in both hematopoietic organs, probably mediated through secondary induced IL-6. However, the important observation from our experiments is that hematopoietic effects of IL-17 on CFU-E are highly dependent on microenvironment and secondary induced ambient regulators, since IL-17 exhibits inhibitory effects in the bone marrow, while in the spleen it is a stimulatory effect. Thus, this complexity of target cells' response, as well as the secondary induced molecules in different organs should be taken into account in the assessment of the therapeutic properties of IL-17.

\section{Acknowledgements}

The excellent technical assistance of Mrs. K. Božanić and Mrs. S. Marković is appreciated. This work was supported by a grant from The Ministry of Science and Environmental Protection, Republic of Serbia (project \#145048).

\section{References}

DE HAAN G, DONTJE B, LOEFFLER M, NIJHOF W: Microenvironmentally dependent effects on murine haemopoiesis by a prolonged interleukin-1 treatment. Br J Haematol 85: 15-19, 1993.

FOSSIEZ F, BANCHEREAU J, MURRAY R, VAN KOOTEN C, GARRONE P, LEBECGUE S: Interleukin-17. Int Rev Immunol 16: 541-551, 1998.

GAFFEN S: Biology of recently discovered cytokines: interleukin-17 - a unique inflammatory cytokine with role in bone biology and arthritis. Arthritis Res Ther 6: 240-246, 2004.

JOVANOVIĆ DV, Di BATTISTA JA, MARTEL-PELLETIER J, JOLICOEUR FC, HE Y, ZHANG M, MINEAU F, PELLETIER J-P: IL-17 stimulates the production and expression of proinflammatory cytokines, IL-1 $\beta$, TNF- $\alpha$, by human macrophages. J Immunol 160: 3513-3521, 1998.

JOVČIĆ G, BUGARSKI D, PETAKOV M, STANKOVIĆ J, STOJANOVIĆ N, MILENKOVIĆ P: Effect of IL-17 on in vitro hematopoietic progenitor cells growth and cytokine release in normal and post-irradiated murine bone marrow. Growth Factors 19: 61-71, 2001.

JOVČIĆ G, BUGARSKI D, PETAKOV M, KRSTIĆ A, VLAŠKI M, STOJANOVIĆ N, MILENKOVIĆ P: In vivo effects of IL-17 on hematopoietic cells and cytokine release in normal mice. Cell Prolif 37: 401-412, 2004.

KISHIMOTO T: The biology of interleukin-6. Blood 74: 1-10, 1989.

MOSELY TA, HAUDENSCHILD DR, ROSE L, REDDI AH: Interleukin-17 family and IL-17 receptors. Cytokine Growth Factor Rev 14: 155-174, 2003. 
MOSMANN T: Rapid colorimetric assay for cellular growth and survival: application to proliferation and cytotoxicity assays. J Immunol 65: 55-63, 1983.

SCHWARZENBERGER P, KOLLS JK: Interleukin 17: an example for gene therapy as a tool to study cytokine mediated regulation of hematopoiesis. $J$ Cell Biochem Suppl 38: 88-95, 2002.

SCHWARZENBERGER P, LA RUSSA V, MILLER A, YE P, HUANG W, ZIESKE A, NELSON S, BAGBY GJ, STOLTZ D, MYNATT RL, SPRIGGS M, KOLLS JK: IL-17 stimulates granulopoiesis in mice: use of an alternate, novel gene therapy-derived method for in vivo evaluation of cytokines. J Immunol 161: 6383-6389, 1998.

SCHWARZENBERGER P, HUANG W, YE P, OLIVER P, MANUEL M, ZHANG Z, BAGBY G, NELSON S, KOLLS JK: Requirement of endogenous stem cell factor and granulocyte-stimulating factor for IL-17 mediated granulopoiesis. J Immunol 164: 4783-4789, 2000.

TARE NS, BOWEN S, WARRIER RR, CARAJAL DM, BENJAMIN WR, RILEY JH, ANDERSON TD, GATELY MK: Administration of recombinant interleukin-12 to mice suppresses hematopoiesis in the bone marrow but enhances hematopoiesis in the spleen. J Interferon Cytokine Res 15: 377-383, 1995.

ULICH TR, DEL CASTILLO J, YIN S, EGRIE JC: The erythropoietic effects of interleukin-6 and erythropoietin in vivo. Exp Hematol 19: 29-34, 1991.

WITOWSKI J, KSIAZEK K, JORRES A: Interleukin-17: a mediator of inflammatory responses. CMLS Cell Mol Life Sci 61: 567-579, 2004.

\section{Reprint requests}

Gordana Jovčić, Institute for Medical Research, Dr Subotića 4, P.O. Box 102, 11129 Beograd, Serbia. Fax: 381112643

691. E-mail: gocaj@imi.bg.ac.yu 